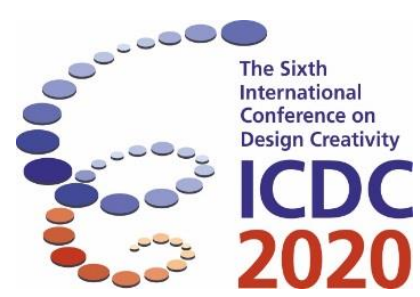

\title{
Bridging Design Thinking and EntreComp for Entrepreneurship Workshops: A Learning Experience
}

\author{
Duncan Campbell ${ }^{1}$, Gerasimos Balis ${ }^{2}$ and Bijan Aryana ${ }^{3}$ \\ ${ }^{1}$ Lancaster Institute for the Contemporary Arts, Lancaster University, Lancaster, UK \\ ${ }^{2}$ Centre for Innovation and Entrepreneurship, University of Bristol, Bristol, UK \\ ${ }^{3}$ Department of Industrial and Materials Science, Chalmers University of Technology, \\ Gothenburg, Sweden
}

\begin{abstract}
Design Thinking (DT) is commonly used in Entrepreneurship Education, however it's capacity to support entrepreneurial competencies has not been explored sufficiently. In this study, we used a multi-method approach to gain an in-depth understanding of participants' learning journeys in two early entrepreneurship events. These were structured around DT and specifically IDEO's implementation of Human Centred Design (HCD). Through semi-structured interviews and nonparticipant observation we were able to link the stages of HCD to specific competencies and identify competencies that manifest across the wider process. We draw conclusions on the contribution of DT in the development of these competencies and make suggestions for using EntreComp to add nuance to DT interventions. Finally we discuss the impact of facilitation, professionalism, customization and logistical factors on the success of DT interventions.
\end{abstract}

Keywords: Design Thinking, Entrepreneurship, Entrepreneurship Education, Entrepreneurial Competencies, EntreComp, Human Centred Design

\section{Introduction}

Design has been viewed as an entrepreneurial tool, especially since the emergence and popularising of Design Thinking (DT) (Brown, 2015; Lackeus, 2015). The current literature exhibits interesting examples of relationships between DT and entrepreneurship (Glen et al., 2014; Nielsen \& Stovang, 2015, Penaluna \& Penaluna 2019). At the same time, some design-oriented frameworks such as design council's double diamond (Design Council, 2005) and IDEO's human centered design toolkit (IDEO, 2015) gained popularity among business and entrepreneurship practitioners, especially in the start-up world. Although there is evidence which shows DT can contribute to the overall success of (often established) businesses (Chłodnicki \& Zieliński, 2009), our knowledge about the way that DT can impact entrepreneurial competencies is still underdeveloped. In fact scholars call for research into how DT informs innovation processes and methods (Micheli et al. 2019). An influential approach in studying and supporting entrepreneurship and entrepreneurial education has been to view it as a competence is defined as "the capacity to act upon opportunities and ideas to create value for others" (McCallum et al., 2018). The EntreComp framework developed by the EU (Bacigalupo et al., 2016) describes the competencies such as spotting opportunities, financial literacy and working with others as a way to "support and inspire actions to improve the entrepreneurial capacity of European citizens and 
organisations" (McCallum et al., 2018). As part of this report, DT is framed as one of the ways to translate or link entrepreneurial competencies to actions, framing it as an "actionable teacher professional development plan" (Odeyemi \& Weicht, 2018).

DT is increasingly used in support of entrepreneurship, for example in workshops run by business incubators. Most nascent entrepreneurs are not DT professionals, which makes it important to explore whether DT adds value in entrepreneurship as assessed against the EntreComp framework for groups of non-specialist participants. This is especially true because DT is criticised as a methodology, and criticised workshops often include non-designer participants. Given the influence both of DT and the Entrecomp framework have had in education and practice, this study aims to answer two questions: RQ1: Do entrepreneurial competencies manifest in the application of DT tools? and RQ2: What are the best practices of applying DT in an entrepreneurship learning workshop? While RQ1 addresses generic aspects of relationships between DT and entrepreneurial competencies, RQ2 is focused on the specific case observed in this study. According to the RQs, the study does not aim to compare DT professionals with non experts. It focuses on using DT in entrepreneurship by not expert practitioners.

\section{Background}

DT is increasingly seen as a domain that can inform entrepreneurship practice (Lackeus 2015; Balis 2018), education (Neck \& Greene 2011) and scholarship (Dimov, 2016; Simon, 1969;). Both fields aim to transform existing environments into preferred ones (Sarasvathy, 2003; Simon, 1969). Similar cycles of identification, research, ideation, making, and evaluation are found in DT and entrepreneurship frameworks. Examples include Stanford DT (Plattner et al., 2010) and Design Sprinting (Knapp et al., 2016) from the DT domain, and the Lean Startup (Ries, 2011) and Effectuation (Sarasvathy, 2009) from entrepreneurship. Despite a lack of consensus around the definition of DT (Kimbell, 2011), the term has gained popularity among entrepreneurs and business leaders (Brown, 2015). Thus, there has been a tendency towards integrating DT and entrepreneurship education (Neck \& Greene, 2011, Nielsen \& Stovang, 2015; Huq \& Gilbert, 2017).

\subsection{Learning in entrepreneurship}

Entrepreneurial learning literature focuses on the study of learning processes in the context of entrepreneurship (Wang \& Chugh, 2015). Various lenses have been applied in understanding how entrepreneurs learn, such as drawing from organisational learning (Politis and Gabrielsson, 2015) and learning at the level of the individual (Cope, 2005). Knowing what skills or competences are involved in entrepreneurial activity is especially relevant in the context of teaching and facilitating learning experiences related to entrepreneurship. According to Lackeus (2015) teaching entrepreneurship could be done theoretically or by engaging with or "doing" entrepreneurship which is called learning through entrepreneurship. EntreComp is a framework of entrepreneurial competencies influenced by experiential learning (Terzaroli, 2018). Kolb's experiential learning theory adopts a constructivist epistemological stance that accounts for affective, cognitive and behavioral aspects of learning (Kolb, 1984). The core mechanic for learning articulated in Kolb's theory is grasping experience and transforming it to knowledge. EntreComp recognises the importance of reflective learning (Kolb, 1984) directly -for example including a competence called "Learning Through Experience" which covers things like reflective learning, learning from successes and failures, leveraging strengths and mitigating weaknesses, and developing strategies.

\subsection{Learning and Entrepreneurial competences in DT}

New knowledge creation occurs in different ways through any design process (Buchanan, 2001) with learning seen as a fundamental aspect of the practice of design, to the extent that it has been framed as a practice of inquiry (Buchanan, 2001, Gero, 1990). This reflects the need to understand the problem and to create value through solving it. Within the context of entrepreneurial learning, DT is framed as a way to change the focus from individual knowledge to team- based collaboration and learning (Lackeus, 2019) which is supported by work viewing the design process as a social learning process that involves listening, reflection and creative thinking (Manzini, 2014). In applying DT for 
Entrepreneurship Education this study focuses on the relevance of such design inquiries and specifically DT to entrepreneurial competences, looking at the competences that are manifested as a result of using DT to develop new ventures.

At a basic level theoretical overlaps between DT and EntreComp can be made through a juxtaposition of the two frameworks, for example, one might argue that the tool "framing a design challenge" maps against the "focus on challenges" thread of the "Spotting opportunities" competency described at the intermediate level as "I can redefine the description of a challenge, so that alternative opportunities to address it may become apparent" (Bacigalupo et al. 2016 p. 179). Instead of going through this exercise for each of the competences in EntreComp we opted for an inductive approach, starting from evidence to inform theory. We did this to look at what people actually do and think which is compatible with the practice oriented methodology adopted.

\section{Setting and Methods}

This study examines the manifestation of EntreComp competencies around DT tool use by nondesigners and non-entrepreneurs. Using an Entrepreneurship-as-Practice approach (Nicolini \& Monteiro, 2016), we observed objects, actions and sayings (Uggerhøj, 2011) in two events where DT tools were used in nascent entrepreneurship. Practice research offers a balance between relevance and rigor (Mathiassen, 2002) dealing with what practitioners actually do. Our research is influenced by Social Practice Theory (Shove et al, 2012) and we consider prior participant knowledge and socio material interactions.

\subsection{The DT interventions}

Business Incubator A (BIA) was helping prepare a DT competition for 220 nascent entrepreneurs. The competition organisers would plan and run the competition (event 2 ), recruit 20 volunteers to be trained as facilitators, and provide the competition brief. BIA would plan the DT competition workshops, make the workshop slides, and train the facilitators (event 1).

Event 1 - Facilitator Training: A professional DT Mentor from BIA trained the 20 facilitators on event 2's DT workshops. The facilitators were new to DT and to facilitation. Event 1 lasted 2 days and included hands-on DT experience as well as broader DT theory to prepare facilitators to respond to questions beyond the practical aspects of the facilitation.

Event 2 - DT Competition: The DT Competition involved 4 days of group activities, some led by Facilitators and others where groups left to collect DT data by methods including interviews and observation. The Facilitator led activities took place in 5 rooms, with roughly 40 participants and a 4 facilitators per room.

The description of events can be seen in Table 1 .

\subsection{Data collection}

Both events were studied by focusing on entrepreneurial competencies observable during sessions and described in self reflection afterwards. We chose to observe manifestation of competencies rather than explore their development over time because the events afforded only 6 days of data collection. One researcher was responsible for collecting and anonymising all data. Collected data included nonparticipant observation, semi-structured interviews and participant reflections. Observations were made every 1 to 5 minutes during the events, with further notes made for an hour afterwards to capture observations in more detail. Interviews were conducted individually to explore self reflection and feelings on DT, and prior knowledge of DT or related approaches. During event 1 the researcher initially observed all 20 facilitators, before focussing on a single group of 5 facilitators to collect richer data. After event 1 the researcher interviewed facilitators from this group to explore their feelings and reflections on event 1, and their feelings towards the upcoming event 2. During event 2 initial observations were made across two rooms before primarily focussing on a single group of 5 participants. After event 2 interviews were conducted with this single group, and with a selection of facilitators from different rooms. Data were stored as per the UK's Freedom of Information Act. 
Table 1. Summary of events

\begin{tabular}{|c|c|c|}
\hline Summary & Event 1: Facilitator Training - 2 days & Event 2: DT Competition - 4 Days \\
\hline Objectives & $\begin{array}{c}\text { DT Mentor from BIA organised and ran 2 } \\
\text { days of facilitator training including: } \\
\text { - Introduction to DT } \\
\text { - Reviewing all stages and contents } \text { event 2 }\end{array}$ & $\begin{array}{c}\text { - Introducing the brief: "Design a digital } \\
\text { service for retired people in 2025" } \\
\text { - Introducing DT and receiving brief } \\
\text { - Working on the brief in DT workshops }\end{array}$ \\
\hline $\begin{array}{c}\text { workshops from } \text { event 2 } \\
\text { - Teach an overview of DT methodology }\end{array}$ & $\begin{array}{c}\text { - develop ideas for innovative service ideas } \\
\text { around the future of retirement } \\
\text { - Create pitch videos to promote ideas }\end{array}$ \\
\hline Facilitation & One professional DT mentor & 20 facilitators \\
\hline Participants & 20 facilitators (in training) & 220 participants \\
\hline Data & $\begin{array}{c}\text { - Fieldnotes from observations of event } \\
\text { - More detailed fieldnotes from observations of } \\
\text { a single table (5 facilitators) }\end{array}$ & $\begin{array}{c}\text { - Observations of 1 room of event 2 (57 } \\
\text { Partipants) }\end{array}$ \\
$\begin{array}{c}\text { - Interviews with facilitators from that single } \\
\text { table }\end{array}$ & $\begin{array}{c}\text { More detailed fieldnotes from observations } \\
\text { of a single table (5 Participants) } \\
\text { - Interviews with participants and facilitators }\end{array}$ \\
\hline
\end{tabular}

\subsection{Data analysis}

Data were analysed through a thematic analysis, to systematically identify, organize and reflect on data based on themes which represent patterns of meaning (Braun et.al, 2019) and make sense of underlying meanings and experiences (ibid). We chose to explore the complex theoretical construct of competence by considering evidence of manifestation across objects-such as clusters of post-it notes, actions-such as a participant deciding to use the whiteboard to explain something) as well as sayings (Uggerhøj, 2011). The interviews helped with the analysis by clarifying how interviewees felt, capturing their reflections on the events and by creating more clarity of the past experiences and prior knowledge of interviewees e.g around entrepreneurship, DT or user research. We also used EntreComp as a sensitizing framework for our analysis, looking specifically for evidence of each competence in our data. Two themes that were identified based on EntreComp competencies are "EntreComp Threads observed within individual DT Phases" (theme 1) and "EntreComp Threads observed across all DT Phases" (theme 2).

\section{Findings}

The main finding of the study is that overwhelmingly most EntreComp competences are indeed manifested as part of the HCD process. We observed two types of manifestation of competences, one relating directly to the use of specific tools, and another that can be considered a by-product of the process. In more detail, we considered competences manifesting directly as a result of the use of the tool when the tool's function was explicitly related to the competency. For example the DT tool "Bundling Ideas" involved the EntreComp Threads "Developing Ideas, Sharing and Protecting Ideas" and "Recognise the Value of Ideas". This is something we could expect to find by comparing the two frameworks theoretically. What was more interesting is that a lot of the competences were manifested although tools did not explicitly relate to them. For example softer competences such as accepting diversity, being determined and inspiring others were supported well by the HCD process without the need for explicit guidance. The connection between competences and the three stages of the process (IDEO, 2015) is presented in Table 2. Competences and sub-threads are presented below for each of the stages of the HCD process.

Looking at the competences that manifested directly as a result of using the tools, we can see that they are spread out across the three competence areas with a focus on ideas and opportunities. On the other hand the by product ones or the competence threads that manifested across the different stages of the process are exclusively under the competence areas of Resources and Into Action. In other words, HCD was especially appropriate for moving the project forward through steps that feed into each other, but did not directly prompt participants to manifest these competences. 
Table 2. Summary of Findings

\begin{tabular}{|c|c|c|c|}
\hline & $\begin{array}{l}\text { DT Phase 1: } \\
\text { INSPIRATION }\end{array}$ & $\begin{array}{l}\text { DT Phase 2: } \\
\text { IDEATION }\end{array}$ & $\begin{array}{c}\text { DT Phase 3: } \\
\text { IMPLEMENTATION }\end{array}$ \\
\hline $\begin{array}{c}\text { DT Tools } \\
\text { used within } \\
\text { individual DT } \\
\text { Phases } \\
\text { (Tools from } \\
\text { the HCD } \\
\text { Toolkit) }\end{array}$ & $\begin{array}{l}\text { Create a project plan - Define } \\
\text { your audience - Interview }\end{array}$ & $\begin{array}{l}\text { Brainstorming - Bundle ideas } \\
\text { - Create frameworks - Create } \\
\text { insight statements - } \\
\text { Determine what to prototype - } \\
\text { Find themes - How might we } \\
\text { - Share inspiring stories - } \\
\text { Storyboard }\end{array}$ & $\begin{array}{l}\text { Create Pitch - Rapid } \\
\text { prototyping }\end{array}$ \\
\hline $\begin{array}{c}\text { EntreComp } \\
\text { threads } \\
\text { observed } \\
\text { within } \\
\text { individual DT } \\
\text { Phases }\end{array}$ & $\begin{array}{c}\text { Define problems - Focus on } \\
\text { challenges - Get support - } \\
\text { Identify, create and seize } \\
\text { opportunities - Make the most } \\
\text { of your time - Manage material } \\
\text { and non-material resources - } \\
\text { Plan and organise -Uncover } \\
\text { needs - Use resources } \\
\text { responsibly }\end{array}$ & $\begin{array}{l}\text { Be innovative - Communicate } \\
\text { effectively - Define problems } \\
\text { Develop ideas - Focus on } \\
\text { challenges - Identify create } \\
\text { and seize opportunities - } \\
\text { Recognise the value of ideas - } \\
\text { Share and protect ideas - Stay } \\
\text { focused and don't give up - } \\
\text { Uncover needs }\end{array}$ & $\begin{array}{l}\text { Develop Ideas - } \\
\text { Communicate } \\
\text { effectively - Recognise } \\
\text { the value of ideas - } \\
\text { Share and protect Ideas } \\
\text { - Using media } \\
\text { effectively }\end{array}$ \\
\hline $\begin{array}{c}\text { EntreComp } \\
\text { threads } \\
\text { that cross all } \\
\text { DT Phases }\end{array}$ & \multicolumn{3}{|c|}{$\begin{array}{l}\text { Accept diversity - Be determined - Don't give up - Get support - Inspire and get inspired - } \\
\text { Learn from experience - Listen actively - Manage material and non-material resources - } \\
\text { Reflect - Stay focused and don't give up - Take action - Take responsibility - Work together }\end{array}$} \\
\hline
\end{tabular}

It is worth mentioning that the only competence we did not see manifest as part of the intervention is the one titled "Ethical and sustainable thinking" in the EntreComp framework. Based on our data and the focus of the HCD process there is no reason to assume this is a result of the HCD process itself, we assume it has to do with the type of the challenge participants were working on. But it would be interesting to explore further in future studies.

\section{Discussion}

Our goal was to explore whether Entrecomp competencies manifest in the application of DT tools (RQ1) and the best practices of applying DT in an entrepreneurship learning workshop (RQ2). Our research involved workshops for 220 total participants run by 21 total facilitators (including DT mentor who actually facilitated the first event) with all workshops being based on the same core material - training, slides and a session plan.

\subsection{Using DT to support the manifestation of EntreComp competences}

Firstly with regards to RQ1, it is clear that overall, the HCD Toolkit and EntreComp map well against one another especially since the HCD Toolkit includes activities around financial literacy and economic sustainability -which isn't true for other DT toolkits that solely focus on product/service development. In more detail, all but one of the 15 EntreComp competencies were observed as part of the interventions of the HCD Toolkit; the lacking EntreComp Competencies involve ethical and environmental factors, financial and economic literacy, and aspects of mobilisation and management. This makes the HCD toolkit a good choice when looking for an "off the shelf" set of activities to use for enterprise education and to support nascent entrepreneurship. It is worth noting that many business accelerators have selection criteria that match more closely to EntreComp than to DT, suggesting that DT alone is not sufficient for entrepreneurship.

\subsection{Using EntreComp to add nuance to $D T$ interventions}

Most importantly, based on our findings we suggest that EntreComp can be used to add nuance to DT interventions beyond the context of enterprise education. This is compatible with EntreComp's broad 
view of what being entrepreneurial is, namely - "discovering and acting upon opportunities and ideas, and transforming them into value or others [...] in any situation" (Bacigalupo 2016 p.13). The additional nuance that EntreComp brings is exemplified in the definition of collaboration, the HCD Toolkit describes collaboration in one line i.e. "Human-centered design works best with cross-disciplinary teams" whereas the EntreComp Competency "Work Together" breaks it down into six threads, each containing up to 8 specific behaviors. That richness and rigor can be used to support different types of DT workshops.

Specifically the EntreComp framework can be a valuable to draw from for the planning and evaluation of DT workshops. In both instances the Progression Model for competence threads can act as a way to benchmark the expertise of groups and help capture the impact of interventions beyond project-specific metrics. In terms of planning a DT workshop, considering the EntreComp competencies allows considering specific participant skills and learning outcomes.

With regards to the evaluation of DT initiatives we recommend that the EntreComp Progression Model is used for a pre-post hoc evaluation of the levels of competency of participants across the most relevant competences/threads. This can help build up a body of knowledge around specific contributions of DT interventions, and help negate critiques around the value of DT. Similarly for practitioners this type of evaluation will help make a more informed case for such interventions and align them with broader organisational goals e.g. around training and capacity building.

\subsection{Beyond the process: A balance of facilitation and professional skills}

Secondly with regards to RQ2 we observed a great variation in factors that contributed to the competences being manifested including the level of facilitator experience, participant motivation and participant language proficiency among others. Two factors were the most important, the experience of facilitators and the level of professional skills of the participants.

Our findings suggest that the skills of the facilitator are especially important when working with novice practitioners. In groups where general professional skills (e.g. EnteComp threads of "Stay Focused and Don't Give Up" and "Work Together") were lacking, facilitation became more important. More experienced facilitators were able to engage with unprofessional groups and help them manifest EntreComp competences. Examples of important facilitation skills we observed were encouraging the quieter people in one's team, actively listening or allocating tasks appropriately within each group. This reflects existing research on facilitation, for example work from McFadzean (2002a, 2002b) and Mosely et al. 2018 that stress the importance of attention to attributes beyond the task itself, like feelings and conceptions. At a basic level, their ability to introduce the challenge, activities and overall process was expected of facilitators. The skills that contributed to highly engaged groups were the ones around managing groups, helping them problem-solve and remove obstacles to productivity.

\subsection{Beyond the process: Customization and Logistics}

Two other factors that emerged as important in engaging participants and supporting them to demonstrate entrepreneurial competences, were Customization and Logistics. These go beyond what is often discussed in the literature of collaborative problem solving for example looking at the Teams and the Facilitator (e.g. McFadzean 2002a, 2002b).

Customization refers to adapting the process to be followed to suit both the participant's skill sets and the strategic reasons the workshop has been commissioned. This can be overlooked when using resources such as the HCD toolkit, but it is worth remembering that tools are built for specific situations and can only be useful when applied to similar problems in similar environments (Furrer \& Thomas, 2000; Narayanan and Fahey, 2005). In this case spending time to shape a relevant and exciting challenge for participants to work on and selecting activities that relate to their knowledge and skills as well as additional tailored material was a key determinant to engagement. Workshop success was strongly influenced by what can be called logistical or background factors. These are basic factors that allow participants to work in a professional manner but can have a big effect on the workshops if they go wrong. For example the temperature of the room and unreliable equipment were seen as key to the experience of participants. Both insights indicate that a lot of the work that leads to good workshops is performed beforehand in managing risks and adapting the material to the organisation. 


\section{Conclusion}

This study links DT and EntreComp empirically, and contributes the insight that the crosspollination of the two frameworks works well both ways, with EntreComp being a valuable addition to the more widely used DT. We propose that Innovation practitioners and DT practitioners should also use EntreComp in their work because it adds important nuance often lacking in DT. Finally, we recommend best practice for using DT with non-designers, in a way that mitigates common critiques of the workshops. In response to RQ1 we concluded that EntreComp competencies can manifest in the application of DT tools, either directly or indirectly, discussing the implications of that. In response to RQ2 we observed three key factors that support the manifestation of these competences, namely facilitation, readiness of participants and customization of the process. We recommend future research on using EntreComp to evaluate the contribution of DT interventions. This will ideally be longitudinal to capture development of competencies over time and to explore factors influencing this development. Also additional research on the difference of running workshops for people with different levels of expertise in DT.

\section{References}

Bacigalupo, M., Kampylis, P., Punie, Y., \& Van den Brande, G. (2016). EntreComp: The entrepreneurship competence framework. Luxembourg: Publication Office of the European Union, 14.

Balis, G. (2018). Learning to design learning through design: service design and experientially acquired entrepreneurial learning. Doctoral dissertation, Lancaster University.

Braun, V., Clarke, V., Hayfield, N., \& Terry, G. (2019). Thematic analysis. Handbook of Research Methods in Health Social Sciences, 843-860.

Brown, T. (2015). When Everyone Is Doing Design Thinking, Is It Still a Competitive Advantage. Harvard Business Review Digital Articles, 27.

Buchanan, R. (2001). Design research and the new learning. Design issues, 17(4), 3-23.

Chłodnicki, M., \& Zieliński, M. (2009). Creating Value by Designing: Economic and Business Perspectives. Journal of Int. Studies, 2(1), 89-98.

Cope, J. (2005). Toward a dynamic learning perspective of entrepreneurship. Entrepreneurship Theory and Practice, 29(4), 373-397.

Design Council (2005). The 'double diamond' design process model. Retrieved from: www.designcouncil.org.uk/news-opinion/what-framework-innovation-design-councils-evolved-double-diamond Dimov, D. (2016). Toward a design science of entrepreneurship. In Models of start-up thinking and action: Theoretical, empirical and pedagogical approaches (pp. 1-31). Emerald Group Publishing Limited.

Furrer, O., \& Thomas, H. (2000). The rivalry matrix: Understanding rivalry and competitive dynamics. European Management Journal, 18(6), 619-637.

Gero, J. S. (1990). Design prototypes: a knowledge representation schema for design. AI magazine, 11(4), 26.

Glen, R., Suciu, C., \& Baughn, C. (2014). The need for design thinking in business schools. Academy of Management Learning \& Education, 13(4), 653-667.

Huq, A., \& Gilbert, D. (2017). All the world's a stage: transforming entrepreneurship education through design thinking. Education+ Training, 59(2), 155-170.

IDEO (2015). The field guide to human-centered design. IDEO.

Jarzabkowski, P., \& Wilson, D. C. (2006). Actionable Strategy Knowledge: A Practice Perspective. European Management Journal, 24(5), 348-367.

Kimbell, L. (2011). Rethinking design thinking: Part I. Design and Culture, 3(3), 285-306.

Knapp, J., Zeratsky, J., \& Kowitz, B. (2016). Sprint: How to solve big problems and test new ideas in just five days. Simon \& Schuster.

Kolb, D. (1984), Experiential Learning: Experience as the Source of Learning and Development. Prentice-Hall. Lackeus M. (2015). Entrepreneurship in Education: What, Why, When, How. Paris: OECD.

Liedtka, J. (2015). Perspective: Linking design thinking with innovation outcomes through cognitive bias reduction. Journal of Product Innovation Management, 32(6), 925-938.

Manzini, E. (2014). Making things happen: Social innovation and design. Design issues, 30(1), 57-66.

Mathiassen, L. (2002). Collaborative practice research. Information Technology \& People, 15(4), 321-345.

McCallum, E., Weicht, R., McMullan, L., \& Price, A. (2018). EntreComp into action-Get inspired, make it happen: A user guide to the European Entrepreneurship Competence Framework. Joint Research Centre. 
McFadzean, E. (2002a). Developing and supporting creative problem solving teams: part 1, a conceptual model. Management Decision, 40(5), 463-475.

McFadzean,E.(2002b). Developing and supporting creative problem solving teams: part 2, facilitator competencies. Management Decision, 40(6), 537-551.

Micheli, P., Wilner, S. J., Bhatti, S. H., Mura, M., \& Beverland, M. B. (2019). Doing design thinking: Conceptual review, synthesis, and research agenda. Journal of Product Innovation Management, 36(2), 124-148.

Mosely, G., Wright, N., \& Wrigley, C. (2018). Facilitating design thinking: A comparison of design expertise. Thinking Skills and Creativity, 27, 177-189.

Narayanan, V. K., \& Fahey, L. (2005). The relevance of the institutional underpinnings of Porter's five forces framework to emerging economies: An epistemological analysis. Journal of Management Studies, 42(1), 207223.

Neck, H. M., \& Greene, P. G. (2011). Entrepreneurship education: known worlds and new frontiers. Journal of small business management, 49(1), 55-70.

Nicolini, D., \& Monteiro, P. (2016). The practice approach: For a praxeology of organisational and management studies. In The Sage handbook of process organization studies (pp. 110-126). Sage.

Nielsen, S. L., \& Stovang, P. (2015). DesUni: university entrepreneurship education through design thinking. Education+ Training, 57(8/9), 977-991.

Odeyemi, O., \& Weicht, R. (2018, June 23). The problems with teacher continuous professional development and how we're fixing them. Retrieved January 13, 2020, from http://entrecompedu.eu/blog-content.php?id=195.

Plattner, H., Meinel, C., \& Leifer, L. (Eds.). (2010). Design thinking: understand-improve-apply. Springer Science \& Business Media.

Penaluna, A., \& Penaluna, K. (2019). 'I'ma designer, get me out of here': can entrepreneurial education advance through learning from design education?. In The Role and Impact of Entrepreneurship Education. Edward Elgar Publishing.

Politis, D., \& Gabrielsson, J. (2015). Modes of learning and entrepreneurial knowledge. Int. Journal of Innovation and Learning, 18(1), 101-122.

Ries, E. (2011). The lean startup: How today's entrepreneurs use continuous innovation to create radically successful businesses. Crown Books.

Sarasvathy, S. D. (2003). Entrepreneurship as a science of the artificial. Journal of Economic Psychology, 24(2), 203-220.

Sarasvathy, S. D. (2009). Effectuation: Elements of entrepreneurial expertise. Edward Elgar Publishing.

Shove, E., Pantzar, M., \& Watson, M. (2012). The dynamics of social practice: Everyday life and how it changes. Sage.

Simon, H. (1969). The Sciences of the Artificial (Vol. 1). The MIT Press.

Storini, C., Binder, T., Linde, P., \& Stuedahl, D. (2015). Designing things together: intersections of co-design and actor network theory. CoDesign: Int. Journal of CoCreation in Design and the Arts, 11(3), 149-151.

Terzaroli, C., 2018. Developing entrepreneurship through Design Thinking: a new frontier for adult education. Epale Journal, 3, 20-27.

Uggerhøj, L. (2011). What is practice research in social work-Definitions, barriers and possibilities. Social Work \& Society, 9(1), 45-59.

Wang, C. L., \& Chugh, H. (2015). Entrepreneurial learning: past research and future challenges. In Entrepreneurial learning (pp. 11-44). Routledge. 